\title{
Pola Kuman Penyebah Ventilator Associated Pneumonia [VAP] dan Sensitivitas Terhadap Antibiotik di RSAB Harapan Kita
}

\author{
Retno Widyaningsih, Latre Buntaran \\ RSAB Harapan Kita, Jakarta
}

Latar belakang. Peningkatan resistensi antibiotik di antara bakteri penyebab pneumonia nosokomial yang didapat di rumah sakit telah banyak dilaporkan. Jika kita tidak mengenal pola kepekaan kuman di suatu rumah sakit akan menyulitkan pemberian terapi empiris awal.

Tujuan. Mengetahui profil kuman penyebab pneumonia yang didapat di rumah sakit pada anak serta uji sensitivitas terhadap beberapa antibiotik.

Metode. Studi deskriptif retrospektif dengan sumber data yang berasal dari rekam medis Laboratorium Mikrobiologi RSAB Harapan Kita periode Januari hingga Juni 2010. Spesimen adalah semua spesimen saluran respiratorik dari pasien dengan diagnosis pneumonia yang dirawat. Biakan dan uji resistensi dilakukan menurut standar National Committee for Clinical Laboratory Standards (NCCLS).

Hasil. Didapatkan 116 spesimen biakan dan di antaranya 4 (3,4\%) steril. Dari 112 biakan positif, 79.5\% di antaranya adalah bakteri gram negatif berturut-turut dari yang paling dominan adalah Pseudomonas sp. (22,4\%), Pseudomonas aeruginosa (18,1\%), Stenotrophomonas maltophilia (9.5\%), Serratia marcescens (8,6\%), Enterobacter aerogenes (7,8\%), Klebsiella pneumonia, Bacillus sp., dan Escherichia coli (masing-masing 5,2\%). Golongan Pseudomonas memiliki sensitivitas terhadap ceftazidime, amikacin serta netilmicin.

Kesimpulan. Basil gram negatif aerob $(79,5 \%)$ merupakan mikroorganisme penyebab yang paling dominan. Ceftazidime, diikuti terhadap amikacin serta netilmicin masih mempunyai sensitivitas yang tinggi sehingga dapat dipakai sebagai terapi awal VAP. Sari Pediatri 2012;13(6):384-90.

Kata kunci: VAP, antibiotik, sensitivitas

Alamat korespondensi:

Dr. Retno Widyaningsih, Sp.A(K). Respirologi Anak RSAB Harapan Kita. Jl. Letjen S. Parman Kav. 87, Slipi Jakarta Barat. Telp. (021) 5668284 Ext.2261, Fax. (021) 5601802

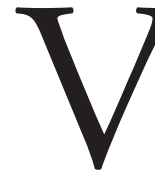

entilator associated pneumonia (VAP) adalah bentuk infeksi rumah sakit yang paling sering ditemui di unit perawatan intensif (UPI), khususnya pada pasien yang menggunakan ventilasi mekanik. ${ }^{1}$ Insiden pneumonia meningkat 3 sampai 10 kali pada pasien dengan ventilasi mekanik., ${ }^{2,3}$ Meskipun belum ada penelitian 
mengenai jumlah kejadian VAP di Indonesia, namun berdasarkan kepustakaan luar negeri diperoleh data bahwa kejadian VAP cukup tinggi, bervariasi antara 9\%-27\% dan angka kematian melebihi 50\%., 2,5

Ventilator associated pneumonia adalah pneumonia yang didapat di rumah sakit yang terjadi setelah 48 jam pasien mendapat bantuan ventilasi mekanik, baik melalui pipa endotrakea maupun pipa trakeostomi. ${ }^{2,6,7}$ Sedangkan American College of Chest Physicians mendefinisikan VAP adalah keadaan gambaran infiltrat baru dan menetap pada foto toraks disertai salah satu tanda yaitu, hasil biakan darah atau pleura sama dengan mikroorganisme yang ditemukan di sputum maupun aspirasi trakea, kavitasi pada foto torak, gejala pneumonia atau terdapat dua dari tiga gejala berikut yaitu demam, leukositosis dan sekret purulen. Ibrahim $\mathrm{dkk}^{6}$ membagi VAP menjadi onset dini yang terjadi dalam empat hari pertama pemberian ventilasi mekanis dan onset lambat yang terjadi lima hari atau lebih setelah pemberian ventilasi mekanik.

Sebagian besar VAP berawal dari aspirasi organisme orofaring ke bronkus distal kemudian terjadi pembentukan biofilm oleh bakteri diikuti dengan proliferasi dan invasi bakteri pada parenkim paru. ${ }^{2}$ Pada keadaan normal, organisme di dalam rongga mulut dan orofaring didominasi oleh Streptococcus viridans, Haemophilus species dan organisme anaerob. ${ }^{3,4}$ Air liur yang mengandung immunoglobulin dan fibronectin menjaga keseimbangan organisme rongga mulut, sehingga jarang didapatkan basil gram negatif aerobik. Namun pada pasien sakit kritis keseimbangan tersebut berubah, organisme yang dominan di dalam rongga mulut adalah basil gram negatif aerobik dan Staphylococcus aureus. ${ }^{2,4,6,8}$

Terapi antibiotik diberikan secara empiris didasarkan pada mikroorganisme etiologi yang menyebabkan VAP pada bayi dan anak sebelum mendapat etiologi pasti dengan menunggu hasil biakan penyebab dan uji resistensi terhadap antibiotik. ${ }^{9}$ Informasi tentang prevalensi berbagai bakteri patogen penyebab pneumonia khususnya VAP dan pola resistensi antibiotik pada pasien pediatri yang dirawat sangat terbatas. Oleh sebab itu pilihan terapi empiris harus dipandu oleh data terkini tentang pola kepekaan kuman yang sering menyebabkan VAP, karena pola kepekaan kuman mungkin berbeda di setiap rumah sakit. Beberapa tahun terakhir, terdapat peningkatan resistensi terhadap antibiotik diantara kuman penyebab utama infeksi respiratorik yang akan membahayakan pilihan pengobatan empiris. Oleh karena itu, perlu dikaji secara akurat pola bakteri yang menyebabkan pneumonia VAP pada anak di setiap rumah sakit untuk memilih antibiotik yang paling sensitif untuk mengendalikan bakteri secara efektif.

Tujuan dari penelitian untuk menentukan pola kuman dan tingkat kerentanan antimikroba dari spesimen saluran respiratorik pasien pneumonia anak khususnya yang menderita VAP yang dirawat di RSAB Harapan Kita.

\section{Metode}

Penelitian deskriptif retrospektif dengan mengambil data hasil biakan dari rekam medis Laboratorium Mikrobiologi RSAB Harapan Kita dari anak dengan diagnosis pneumonia yang dirawat periode Januari - Juni 2010. Spesimen biakan diambil dari saluran respiratorik (sekret bronkus, sekret tenggorok, cairan pleura, sekret dari ujung ETT). Isolasi bakteri dilakukan dengan suatu sengkelit spesimen pemeriksaan yang diinokulasi pada plat agar darah dan agar endo. Setelah diinkubasi 18-24 jam, koloni bakteri yang tumbuh diseleksi dan dilakukan pewarnaan Gram. Koloni bakteri dimurnikan, bakteri diidentifikasi berdasarkan morfologi koloni dan kuman, sifat gram, daya hemolisa, serta uji biokimia lain. Untuk bakteri Streptokokus dilakukan juga uji kepekaan terhadap optochin dan bacitracin secara cakram dan untuk bakteri Stafilokokus dilakukan uji koagulase. Pengujian sensitivitas bakteri dilakukan menurut cara difusi cakram mengacu pada pengerjaan dan interpretasi hasil dari NCCLS. Bakteri yang telah dimurnikan, disuspensikan dalam kaldu sampai kepekatannya 0,5 McFarland. Suspensi bakteri diinokulasikan secara merata pada plat agar Muller Hilton. Seluruh bakteri yang ditemukan diuji sensitivitas terhadap 16 jenis antibiotik.

\section{Hasil}

Diperoleh 116 spesimen saluran respiratorik berasal dari pasien VAP dan non- VAP. Spesimen terdiri atas 88 $(75,9 \%)$ spesimen sekret bronkus, $20(17,2 \%)$ spesimen sekret tenggorok, $6(5,2 \%)$ spesimen sekret ujung ETT, dan $2(1,7 \%)$ spesimen cairan pleura. Di peroleh hasil 4 spesimen $(3,4 \%)$ steril, 112 biakan positif dengan 15 jenis mikroorganisme penyebab infeksi berturut-turut dari 
Distribusi bakteri ( $\mathrm{n}=116)$

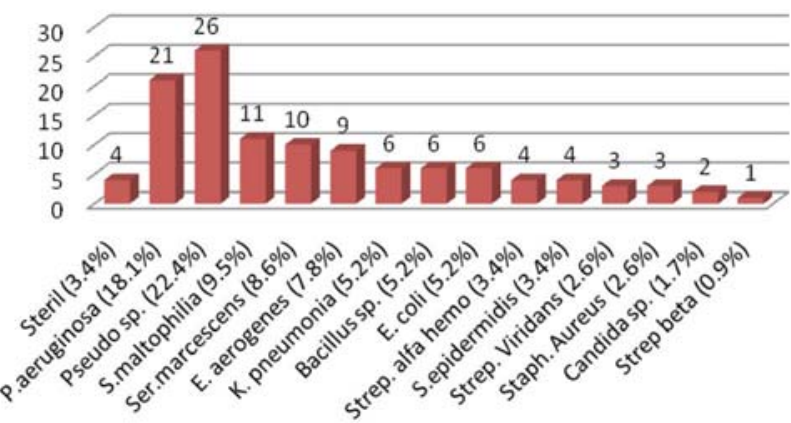

Gambar 1. Distribusi bakteri penyebab

yang paling dominan adalah Pseudomonas sp. $(22,4 \%)$, Pseudomonas aeruginosa (18,1\%), Stenotrophomonas maltophilia (9,5\%), Serratia marcescens (8,6\%), Enterobacter aerogenes (7,8\%), Klebsiella pneumonia, Bacillus sp., dan Escherichia coli (5,2\%), Streptococcus $\alpha$ haemolyticus dan Staphylococcus epidermidis (3,4\%), Streptococcus viridians dan Staphylococcus aureus (2,6\%); Candida sp. (1,7\%), serta Streptococcus $\beta$ haemolyticus $(0,9 \%)$ (Tabel 1). Bila dikelompokkan, 79,5\% di antaranya adalah bakteri gram negatif (Pseudomonas, S. maltophilia, Serratia marcescens, E. aerogenes, $K$. pneumonia, dan E. coli) (Gambar 1).
Sebagai etiologi infeksi saluran napas yang dominan, $P$. aeruginosa memiliki sensitivitas terbesar terhadap ceftazidime, diikuti terhadap amikacin serta netilmicin, sedangkan mikroorganisme terbanyak, Pseudomonas sp. mempunyai sensitivitas rendah terhadap semua jenis antibiotik dengan sensitivitas tertinggi terhadap ciprofloxacin (Tabel 1).

Untuk melihat pola bakteri berdasarkan onset VAP, isolat kultur dikelompokkan berdasarkan hari pengambilan sampel. Kasus VAP onset dini diambil pada hari rawat ke 1-4 dan VAP onset lambat yang diambil pada hari rawat ke 5 atau lebih. Dari 112 isolat kultur yang positif, didapatkan 23 sampel VAP onset dini (Gambar 2) dan 73 sampel VAP onset lambat (Gambar 3). Kuman VAP onset dini paling dominan adalah $P$. aeruginosa, dengan sensitivitas tertinggi terhadap antibiotik amikasin dan ceftazidime (Tabel 2). Pada VAP onset lambat paling dominan adalah Pseudomonas sp, diikuti $P$. aeruginosa, S. maltophilia dan Serratia marcescens, dengan pola sensitivitas terhadap antibiotik tertinggi kuman Pseudomonas sp adalah terhadap amikasin dan ciprofloxacine. Sedangkan P.aeruginosa masih sensitif terhadap beberapa antibiotik yaitu terhadap amikasin, netilmisin dan ceftazidime masing-masing, diikuti terhadap ciprofloxacine, imipenem, dan meropenem (Tabel 3).

Tabel 1. Sensitivitas bakteri terhadap antibiotik

\begin{tabular}{|c|c|c|c|c|c|c|c|c|c|c|c|c|c|c|c|c|}
\hline \multirow{2}{*}{ Bakteri (n) } & \multicolumn{16}{|c|}{ Persentase sensitivitas kuman terhadap antibiotik $(n=112)$} \\
\hline & $\mathrm{AM}$ & SAM & AN & NET & SXT & $\mathrm{C}$ & $\mathrm{TE}$ & CXM & CTX & $\mathrm{CRO}$ & CAZ & IPM & MEM & NA & CIP & $\mathrm{KZ}$ \\
\hline P.aeruginosa (21) & 0 & 0 & 19 & 19 & 0 & 0 & 0 & 0 & 7 & 9 & 20 & 10 & 10 & 1 & 14 & 0 \\
\hline Pseudomonas sp. (26) & 0 & 1 & 16 & 12 & 5 & 1 & 5 & 3 & 4 & 5 & 11 & 8 & 5 & 8 & 17 & 1 \\
\hline S.maltophilia (11) & 0 & 1 & 2 & 1 & 5 & 8 & 1 & 2 & 3 & 3 & 8 & 4 & 1 & 3 & 6 & 0 \\
\hline Ser.marcescens (10) & 0 & 0 & 4 & 5 & 5 & 6 & 10 & 0 & 4 & 5 & 6 & 8 & 5 & 8 & 10 & 0 \\
\hline E. aerogenes (9) & 0 & 0 & 5 & 3 & 1 & 4 & 1 & 1 & 2 & 2 & 2 & 8 & 5 & 4 & 7 & 0 \\
\hline$K$. pneumonia (6) & 0 & 0 & 5 & 4 & 1 & 3 & 2 & 0 & 0 & 0 & 0 & 5 & 5 & 3 & 2 & 0 \\
\hline Bacillus sp. (6) & 2 & 2 & 6 & 5 & 2 & 4 & 4 & 2 & 2 & 2 & 1 & 5 & 5 & 2 & 5 & 3 \\
\hline E. $\operatorname{coli}(6)$ & 2 & 3 & 4 & 3 & 2 & 4 & 3 & 3 & 3 & 3 & 3 & 5 & 5 & 4 & 5 & 2 \\
\hline Strep. alfa hemo (4) & 3 & 3 & 1 & 2 & 1 & 4 & 2 & 1 & 4 & 4 & 2 & 4 & 3 & 0 & 4 & 2 \\
\hline S.epidermidis (4) & 1 & 3 & 3 & 3 & 3 & 2 & 3 & 1 & 1 & 1 & 0 & 3 & 2 & 0 & 2 & 1 \\
\hline Strep. Viridans (3) & 0 & 1 & 2 & 2 & 0 & 2 & 2 & 0 & 2 & 2 & 0 & 2 & 1 & 0 & 3 & 0 \\
\hline Staph. Aureus (3) & 0 & 2 & 3 & 3 & 2 & 3 & 2 & 2 & 2 & 2 & 0 & 2 & 1 & 0 & 3 & 1 \\
\hline Candida sp. (2) & 0 & 0 & 0 & 0 & 0 & 0 & 0 & 0 & 0 & 0 & 0 & 0 & 0 & 0 & 1 & 0 \\
\hline Strep.beta hemo (1) & 1 & 1 & 0 & 1 & 1 & 0 & 0 & 0 & 0 & 0 & 0 & 1 & 1 & 0 & 1 & 0 \\
\hline
\end{tabular}

Keterangan: AM Ampicillin; SAM Ampicillin/sulbactam; AN Amikacin; NET Netilmicin; SXT Sulphamethoxazole/thrimethoprim; C Chloramphenicol; TE Tetrasiklin; CXM Cefuroxime; CTX Cefotaxime; CRO Ceftriaxone; CAZ Ceftazidime; IPM Imipenem; MEM Meropenem; NA Nalidisic acid; CIP Ciprofloxacin; KZ Cefazolin 


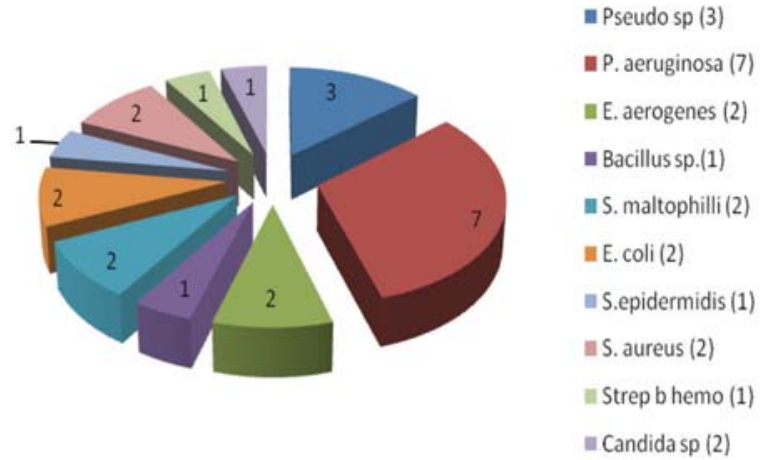

Gambar 2. Distribusi bakteri VAP onset dini $(\mathrm{n}=23)$

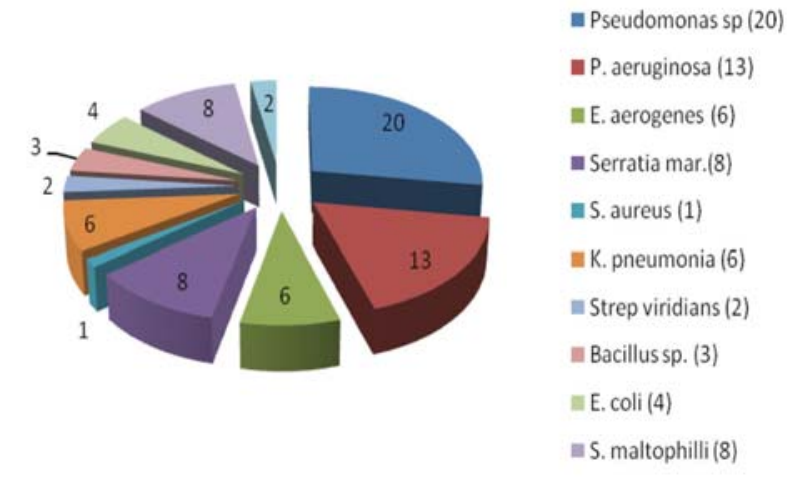

Gambar 3. Distribusi bakteri VAP onset lambat $(\mathrm{n}=73)$

Tabel 2. Sensitivitas bakteri VAP onset dini terhadap antibiotik

\begin{tabular}{lcccccccccccccccccc}
\hline \multirow{2}{*}{ Kuman (n) } & \multicolumn{11}{c}{ Persentase sensitivitas kuman terhadap antibiotik (n=23) } \\
& AM & SAM & AN & NET & SXT & C & TE & CXM & CTX & CRO & CAZ & PPM & MEM & NA & CIP & KZ \\
\hline Pseudomonas sp (3) & 0 & 0 & 3 & 1 & 0 & 0 & 0 & 0 & 1 & 1 & 1 & 3 & 3 & 0 & 3 & 2 \\
P. aeruginosa (7) & 0 & 0 & 7 & 6 & 0 & 0 & 0 & 0 & 3 & 4 & 7 & 4 & 3 & 0 & 4 & 0 \\
E. aerogenes (2) & 0 & 0 & 1 & 0 & 0 & 2 & 0 & 0 & 0 & 0 & 0 & 2 & 2 & 0 & 2 & 0 \\
S. aureus (2) & 0 & 1 & 2 & 2 & 1 & 2 & 1 & 1 & 1 & 1 & 0 & 1 & 0 & 0 & 2 & 1 \\
Strep b hemo (1) & 1 & 1 & 0 & 1 & 1 & 0 & 0 & 0 & 0 & 0 & 0 & 1 & 1 & 0 & 1 & 0 \\
Bacillus sp.(1) & 1 & 1 & 1 & 1 & 1 & 1 & 1 & 1 & 1 & 1 & 0 & 1 & 1 & 0 & 1 & 1 \\
E. coli (2) & 1 & 1 & 1 & 1 & 0 & 1 & 1 & 0 & 0 & 0 & 0 & 1 & 1 & 1 & 2 & 0 \\
S. maltophilli (2) & 0 & 0 & 1 & 0 & 1 & 2 & 1 & 0 & 1 & 1 & 2 & 0 & 0 & 1 & 1 & 0 \\
S.epidermidis (1) & 1 & 1 & 1 & 1 & 1 & 1 & 1 & 1 & 1 & 1 & 0 & 1 & 1 & 0 & 1 & 1 \\
Candida sp (2) & 0 & 0 & 0 & 0 & 0 & 0 & 0 & 0 & 0 & 0 & 0 & 0 & 0 & 0 & 1 & 0 \\
\hline
\end{tabular}

Keterangan: AM Ampicillin; SAM Ampicillin/sulbactam; AN Amikacin; NET Netilmicin; SXT Sulphamethoxazole/thrimethoprim; C Chloramphenicol; TE Tetrasiklin; CXM Cefuroxime; CTX Cefotaxime; CRO Ceftriaxone; CAZ Ceftazidime; IPM Imipenem; MEM Meropenem; NA Nalidisic acid; CIP Ciprofloxacin; KZ Cefazolin

Tabel 3. Sensitivitas bakteri VAP onset lambat terhadap antibiotik

\begin{tabular}{lccccccccccccccccc}
\hline \multirow{2}{*}{ Kuman (n) } & \multicolumn{11}{c}{ Persentase sensitivitas kuman terhadap antibiotik (n=73) } \\
& AM & SAM & AN & NET & SXT & C & TE & CXM & CTX & CRO & CAZ & IPM & MEM & NA & CIP & KZ \\
\hline Pseudomonas sp (20) & 0 & 0 & 12 & 9 & 3 & 1 & 4 & 1 & 1 & 2 & 8 & 3 & 2 & 5 & 12 & 0 \\
P. aeruginosa (13) & 0 & 0 & 11 & 12 & 0 & 0 & 0 & 0 & 4 & 5 & 12 & 5 & 6 & 1 & 9 & 0 \\
E. aerogenes (6) & 0 & 0 & 3 & 3 & 1 & 1 & 1 & 1 & 2 & 2 & 2 & 5 & 2 & 4 & 5 & 0 \\
Serratia mar.(8) & 0 & 0 & 4 & 4 & 5 & 5 & 0 & 0 & 4 & 4 & 5 & 6 & 4 & 7 & 8 & 0 \\
S. aureus (1) & 0 & 1 & 1 & 1 & 1 & 1 & 1 & 1 & 1 & 1 & 0 & 1 & 1 & 0 & 1 & 0 \\
K. pneumonia (6) & 0 & 0 & 5 & 4 & 1 & 3 & 2 & 0 & 0 & 0 & 0 & 5 & 5 & 3 & 2 & 0 \\
Strep viridians (2) & 0 & 1 & 1 & 1 & 0 & 1 & 1 & 0 & 1 & 1 & 0 & 1 & 1 & 0 & 2 & 0 \\
Bacillus sp. (3) & 0 & 0 & 3 & 2 & 0 & 2 & 2 & 0 & 0 & 0 & 0 & 3 & 2 & 1 & 3 & 1 \\
E. coli (4) & 1 & 2 & 3 & 2 & 2 & 3 & 2 & 3 & 3 & 3 & 3 & 4 & 4 & 3 & 3 & 2 \\
S. maltophilli (8) & 0 & 1 & 1 & 1 & 3 & 6 & 0 & 2 & 2 & 2 & 5 & 3 & 1 & 2 & 5 & 0 \\
S. epidermidis (2) & 0 & 1 & 1 & 1 & 1 & 1 & 2 & 0 & 0 & 0 & 0 & 1 & 0 & 0 & 1 & 0 \\
\hline
\end{tabular}

Keterangan: AM Ampicillin; SAM Ampicillin/sulbactam; AN Amikacin; NET Netilmicin; SXT Sulphamethoxazole/thrimethoprim; C Chloramphenicol; TE Tetrasiklin; CXM Cefuroxime; CTX Cefotaxime; CRO Ceftriaxone; CAZ Ceftazidime; IPM Imipenem; MEM Meropenem; NA Nalidisic acid; CIP Ciprofloxacin; KZ Cefazolin 


\section{Pembahasan}

Beberapa kuman penyebab VAP pada neonatus, bayi, dan anak dianggap sama dengan spesimen dari orang dewasa. ${ }^{10-17}$ Pseudomonas aeruginosa, Klebsiella spesies, spesies Enterobacter, dan Haemophilus influenzae nontypable adalah kuman penyebab gram negatif yang paling umum. Staphylococcus, termasuk yang barubaru ini muncul dengan strain methicillin resisten, juga telah dilaporkan sebagai isolate kuman gram-positif yang banyak ditemukan.

Pada penelitian epidemiologi bakteri patogen saluran respiratori oleh Varotto $\mathrm{dkk},{ }^{18}$ didapatkan terbanyak adalah $P$. aeruginosa (24\%) diikuti oleh $S$. pyogenes (18\%), S. aureus (17\%) dan K. pneumonia (8\%). Penelitian di India oleh Kumari dkk, ${ }^{19}$ melaporkan bahwa isolate dari saluran respiratori pasien anak di UPI terbanyak adalah $P$. aeruginosa, diikuti Klebsiella $s p p$ dan Enterobacter $s p p$ berturut sebanyak $21.5 \%, 19.8 \%$ dan $6.2 \%$.

Seperti tertera pada Tabel 1, hasil penelitian didominasi oleh kuman gram negatif (79,5\%). Dibandingkan dengan dua penelitian Varotto $\mathrm{dkk}^{18}$ dan Kumari dkk, ${ }^{19}$ predominan kuman penyebab hampir sama yaitu $P$. aeruginosa dan Pseudomonas. sp. Bakteri gram negatif lainnya seperti Klebsiella dan Enterobacter didapatkan dalam persentase yang lebih rendah.

Ventilator associated pneumonia (VAP) onset dini yang terjadi pada empat hari pertama perawatan di UPI pada umumnya memiliki prognosis lebih baik karena disebabkan oleh kuman yang masih sensitif terhadap antibiotik. Ventilator associated pneumonia onset lambat yang terjadi setelah lima hari atau lebih perawatan memiliki prognosis yang lebih buruk karena disebabkan oleh kuman patogen yang multidrug resistance (MDR)., ${ }^{60-22}$ Penelitian di China mendapatkan $15,47 \%$ kasus VAP onset dini dan $84,53 \%$ VAP onset lambat, dengan jenis patogen utama onset dini adalah respiratory syncytial virus (RSV), Streptococcus mitis, Streptococcus pneumonia, Haemophilus influenzae dan Klebsiella pneumoniae. Sedangkan pathogen onset lambat adalah ESBLspositive Klebsiella pneumonia, Stenotrophomonas maltophilia, Burkholderia cepacia, Escherichia coli, dan Acinetobactor baumanni. ${ }^{23}$

Pada penelitian kami didapatkan hasil yang berbeda, spesimen yang diambil pada hari 1-4 dan hari ke 5-8 perawatan di UPI didapatkan distribusi kuman penyebab paling dominan adalah bakteri gram negatif.
Pada kasus infeksi di rumah sakit dan pada kasus yang mempunyai underlying disease banyak diisolasi bakteri Gram negatif. Terdapat beberapa kemungkinan penyebab dari fenomena ini, antara lain karena tidak tepat pemberian antimikroba dalam terapi empiris dan kurang tepat strategi pengendalian infeksi. ${ }^{24}$ Melihat gambaran isolat yang didapat dari penelitian kami, agaknya memang telah terjadi pergeseran kuman penyebab VAP menjadi kuman gram negatif yang paling dominan dan isolasi bakteri gram negatif yang tinggi belum dapat dipastikan sebabnya.

Peningkatan populasi kuman gram negatif di rumah sakit akan menyebabkan problem terapi di banyak tempat di seluruh dunia, terutama di negara berkembang. ${ }^{19}$ Resistensi antibiotik menyebabkan penetrasi antimikroba terbatas, sehingga konsentrasi terapetik sulit dicapai. Hal tersebut akan menghambat eradikasi kuman pada infeksi respiratorik yang diobati dengan menggunakan regimen terapi standar antibiotik. Berdasarkan kenyataan tersebut maka diperlukan informasi yang akurat tentang epidemiologi lokal dan pola resistensi antimikroba patogen pada anak karena sangat penting untuk memilih terapi antibiotik yang secara klinis efektif untuk mengobati infeksi.

Pada pengamatan penelitian kami, resistensi tertinggi terhadap antibiotik terutama terdapat pada kuman Pseudomonas, Klebsiella dan E. coli, hal sesuai dengan hasil penelitian oleh Kumari dkk. ${ }^{19}$ Pada penelitian di India pola resistensi antibiotik bakteri gram negatif dari isolat sekret respiratori bawah, resistensi tertinggi terjadi adalah terhadap ampisilin $(96.6 \%)$ dan terendah terhadap amikasin (28\%). ${ }^{25}$ Dibandingkan dengan laporan dari Iran, laju peningkatan resistensi antibiotik terlihat di antara bakteri Acinetobacter spp. dan $P$. aeruginosa. ${ }^{26-28}$ Pada penelitian kami, resistensi antibiotik tertinggi juga didapatkan terhadap golongan antibiotik ampisilin, namun terendah terhadap ciprofloxacin.

Pilihan terapi empiris awal pada pasien pneumonia didapat dari rumah sakit yang dirawat di UPI RSAB Harapan Kita adalah golongan cefotaxim atau ceftriaxone. Seperti penelitian Kumari, ${ }^{19}$ kuman terbanyak yang ditemukan adalah Pseudomonas, sama dengan temuan kami. Sensitivitas terhadap antibiotik dari kuman yang diambil saat awal hari 1-4 dan hari ke 5-8, didapatkan tertinggi terhadap golongan amikasin, ceftazidim dan netilmicin, sehingga terapi awal untuk pneumonia di UPI RSAB Harapan Kita dianjurkan menggunakan antibiotik tersebut sampai terdapat hasil biakan. 


\section{Kesimpulan}

Kami mendapatkan penyebab VAP tersering adalah bakteri gram negatif yang memiliki tingkat resistensi yang tinggi terhadap antibiotik. Dalam upaya mengurangi morbiditas dan mortalitas akibat pneumonia rumah sakit khususnya VAP, maka diperlukan pengujian berkala pola kuman penyebab pneumonia dan sensitivitasnya terhadap antibiotik. Pembuatan pola kuman di tiap rumah sakit akan membantu dalam perumusan kebijakan antibiotik rasional. Amikasin, ceftazidim, dan netilmicin masih menunjukkan sensitivitas yang tinggi terhadap kuman penyebab utama VAP di RSAB Harapan Kita, sehingga dapat digunakan sebagai terapi lini pertama pada pengobatan awal VAP.

\section{Daftar pustaka}

1. Porzecanski I, Bowton DL. Diagnosis and treatment of ventilator associated pneumonia. Chest 2006;130:597604.

2. Chastre J, Fagon JY. Ventilator associated pneumonia. Am J Respir Crit Care Med 2002;65:67-903.

3. Rello J, Lorente C, Diaz E, BodiM, Boque C, SandiumengeA, dkk. Incidence, etiology and outcome of nosocomial pneumonia in ICU patients requiring percutaneous tracheotomy for mechanical ventilation. Chest 2003;124:2239-11

4. Kollef M. Prevention of hospital-associated pneumonia and ventilator associated pneumonia. Crit Care Med 2004;32:1396-405.

5. Sallam SA, Arafa MA, Razek AA, Naga M, Hamid MA. Device-related nosocomial infection in intensive care units of Alexandria University Students Hospital. Eastern Mediterranean Health Journal 2005;11:52-61.

6. Ibrahim EH, Ward S, Sherman G, Kollef MH. A comparative anlysis of patients with early-oset vs lateonset nosocomial pneumonia in the ICU setting. Chest 2000;117:1434-42

7. Rello J, Paiva JA, Baraibar J, Barcenilla F, Bodi M, Castander D, dkk. International conference for the development of consensus on the diagnosis and treatment of ventilator associated pneumonia. Chest 2001;120:955-70.

8. Pesola GR. Ventilator associated pneumonia in institutionalized elders. Are teeth a reservoir for respiratory pathogens? Chest 2004;126:1401-3.
9. Sadeli M. Pattern of bacteria causing pneumonia in children and its sensitivity to some antibiotics. Proc ASEAN Congr Trop Med Parasitol 2008;3:121-4.

10. Raymond J, Aujard Y. Nosocomial infections in pediatric patients: a European, multicenter prospective study. European Study Group. Infect Control Hosp Epidemiol 2000; 21:260-3.

11. Elward AM, Warren DK, Fraser VJ. Ventilator-associated pneumonia in pediatric intensive care unit patients: risk factors and outcomes. Pediatrics 2002; 109:758-64.

12. Srinivasan R, Asselin J, Gildengorin G, WienerKronish J, Flori HR. A prospective study of ventilatorassociated pneumonia in children. Pediatrics 2009; 123:1108-15.

13. Apisarnthanarak A, Holzmann-Pazgal G, Hamvas A, Olsen MA, Fraser VJ. Ventilator-associated pneumonia in extremely preterm neonates in a neonatal intensive care unit: characteristics, risk factors, and outcomes. Pediatrics 2003; 112:1283-9.

14. Almuneef $\mathrm{M}$, Memish ZA, Balkhy $\mathrm{HH}$, Alalem $\mathrm{H}$, Abutaleb A. Ventilatorassociated pneumonia in a pediatric intensive care unit in Saudi Arabia: a 30-month prospective surveillance. Infect Control Hosp Epidemiol 2004; 25:753-8.

15. Bigham MT, Amato R, Bondurrant P. Ventilatorassociated pneumonia in the pediatric intensive care unit: characterizing the problem and implementing a sustainable solution. J Pediatr 2009; 154:582-7.

16. Labenne M, Poyart C, Rambaud C, et al. Blind protected specimen brush and bronchoalveolar lavage in ventilated children. Crit CareMed 1999;27:2537-43.

17. Gauvin F, Lacroix J, Guertin MC. Reproducibility of blind protected bronchoalveolar lavage in mechanically ventilated children. Am J Respir Crit Care Med 2002; 165:1618-23.

18. Varotto,F, GD Maria, R. Azzaro, P. Bellissima, R. Amato. An observational study on the epidemiology of respiratory tract bacterial pathogens and their susceptibility to four injectable beta-lactam antibiotics piperacillin, piperacillin tazobactam, ceftazidime and ceftriaxone. J Chemother 2001;13:413-23.

19. Kumari, HBV, S Nagarathna and A. Chandramuki. Antimicrobial resistance pattern among aerobic gram begative bacilli of lower respiratory tract specimens of intensive care unit patients in neurocenter. Indian J Chest Dis Allied Sci 2007;49:19-22.

20. Niederman MS, Craven DE, Bonten MJ. American thoracic society documents: Guidelines for the management of adults with hospital-acquired, ventilator- 
associated, and healthcare-associated pneumonia. Am J Respir Crit Care Med 2005;171:388-416.

21. Torres A, Ewig S. Diagnosing ventilatorassociated pneumonia. N Engl J Med 2004;350:433-5.

22. Ioanas M, Ferrer R, Angrill J, Ferrer M, Torres A. Microbial investigation in ventilator-associated pneumonia. Eur Respir J 2001;17:791-801.

23. Wang P, Dong L, Zhang L, Xia LJ. Etiology and epidemic characteristics of hospital acquired pneumonia in children. Zhonghua Er Ke Za Zhi 2010; 48:465-8.

24. Agus Sjahrurachman, Ikanungsih, Conny RT, Aryani K, Tjahjani MS, Pratiwi S. Pola kuman infeksi saluran pernapasan bawah dan kepekaannya terhadap berbagai antibiotik. Cermin Dunia Kedokteran 2002;137:37-40.
25. Navneeth, BV and MR Sandhya Balwadi. Antibiotic resistance among gram-negative bacteria of lower respiratory tract secretions in hospitalized patients. Indian J Chest Dis Allied Sci 2002;44:173-6.

26. Ranjbar R, N. Sadeghifard, A Ahmadi, M Izadi, J Zaemi-Yazdi. Antimicrobial susceptibility and AP-PCR typing of Acinetobacter spp. Strains. Iran J Publ Health 2007;36:50-6.

27. Shirazi MM, R Ranjbar, F Hemati, N Sadeghifard. Bacterial infections in renal transplant recipients. Iran J Publ Health 2005;34:62-6.

28. Shirazi MM, R Ranjbar. A Survey of bacterial infections in bone marrow transplant recipients. Iran J Publ Health 2007;36:77-81. 